\title{
Rabies Vaccination Coverage and Antibody Profile of Owned Dogs in Abuja, Nigeria
}

\author{
Grace O. Olayemi ${ }^{\star 1}$, Jarlath U. Umoh ${ }^{1}$, Grace S. Kia ${ }^{1}$ and Asabe A. Dzikwi ${ }^{2}$ \\ ${ }^{1}$ Veterinary Public Health and Preventive Medicine, Ahmadu Bello University Zaria, Zaria, Nigeria; ${ }^{2}$ University of Jos, Department of \\ Vet Public Health, Jos, Nigeria
}

\section{Objective}

To determine the vaccination status of owned dogs, assess the rabies antibody titre of vaccinated dogs and risk factors associated with vaccination of dogs in Abuja, Nigeria.

\section{Introduction}

Rabies is a zoonotic disease of high public health importance'. There have been documented reports of rabies in vaccinated $\operatorname{dogs}^{2}$. Rabies is enzootic in domestic dogs in Nigeria. Hence, annual vaccination campaigns of dogs are advocated with the aim of rabies elimination. Vaccination status, type of vaccination and the immunogenicity of the various rabies vaccines used in Abuja Nigeria has not been studied. To date, no effective medical therapy has been established for rabies ${ }^{3}$. Most human rabies deaths occur in the developing countries and though effective and economical control measures are available their application in developing countries is hampered by a range of economic, social and political factors. It is widely recognized that the number of deaths officially reported in most developing countries greatly underestimates the true incidence of disease, with several factors contributing to widespread underreporting ${ }^{3}$. Preventive vaccination against rabies virus is a highly effective method for preventing rabies in humans and animals ${ }^{3}$ but do people vaccinate and how long does the immunity conferred by the vaccine remain protective in the dogs in Abuja?. Rabies has high financial expenditure burden on any country where it is endemic mainly associated with costs incurred on post-exposure prophylaxis (determined by the type of vaccine, vaccine regimen and route of administration as well as the type of immunoglobulin used).

\section{Methods}

Dog serum samples $(n=276)$ were collected from Abuja the Federal Capital Territory (FCT) Nigeria, from 5 locations (Phase 1, 2, 3, Gwagwalada and Kubwa) based on availability and owners consent. Rabies antibody serum titer was determined using an indirect enzyme linked immuno-sorbent assay. Face to face structured questionnaires were used to obtain demographic and zoographic information from the dog owners. Associations between the demographic variables, vaccination status and rabies antibody titer of each dog were assessed using $\chi^{2}$ analysis.

\section{Results}

Of the dogs sampled, $229(83 \%)$ had certified antirabies vaccination record. The dogs sampled, which were vaccinated from Phase I, II, III and the satellite towns were; 109/118 (92.37\%), 32/33 (96.97\%), $48 / 49(97.96 \%)$ and $40 / 76(52.63 \%)$, respectively. A total of 276 serum samples were collected, processed and analyzed during this study. Out of the 276 dogs sampled, 239 (86.6\%) had rabies antibody titre $\geq 0.6 \mathrm{EU} / \mathrm{ml}$ whilst $37(13.4 \%)$ had less than $0.6 \mathrm{EU} / \mathrm{ml}$. There was a marked decline in rabies antibody titre with increase in time.

Out of the 228 exotic breeds of dogs sampled, 218 (95.6\%) were vaccinated whilst $11(22.9 \%)$ of the 48 indigenous breed of dogs sampled were vaccinated. All the exotic breed of dogs had rabies antibody titre $\geq 0.6 \mathrm{EU} / \mathrm{ml}$ whilst $37(77.1 \%)$ of the indigenous breed of dogs had less than $0.6 \mathrm{EU} / \mathrm{ml}$ levels of rabies antibody titre.
All dogs within 6 months to 1 year and greater than 10 years of age $\mathrm{had} \geq 0.6 \mathrm{EU} / \mathrm{ml}$ rabies antibody titre whilst dogs within $1-5$ years had $1(0.5 \%)$ and $36(69.2 \%)$ dogs of age $6-10$ years had rabies antibody titre $<0.6 \mathrm{EU} / \mathrm{ml}$. Twelve $(7.6 \%)$ of the males and $25(21.2 \%)$ of the females had less than $0.6 \mathrm{EU} / \mathrm{ml}$ rabies antibody titre. All the dogs acquired by importation and from breeders had rabies antibody titre $\geq 0.6 \mathrm{EU} / \mathrm{ml}$ whilst 37 (27.2\%) of the dogs acquired from friends had less than $0.6 \mathrm{EU} / \mathrm{ml}$ rabies antibody titre.

Significant associations were observed between breed $\left(\chi^{2}=203\right.$, $\mathrm{df}=1, \mathrm{P}$-value $<0.05)$, age $\left(\chi^{2}=172, \mathrm{df}=3, \mathrm{P}\right.$-value $\left.<0.05\right)$, sex $\left(\chi^{2}=10.75, \mathrm{df}=1, \mathrm{P}\right.$-value $\left.<0.05\right)$, source $\left(\chi^{2}=43.99, \mathrm{df}=2\right.$, P-value $<0.05)$, rabies vaccination status $\left(\chi^{2}=276.00, \mathrm{df}=2, \mathrm{P}\right.$-value $\left.<0.05\right)$ and the rabies antibody prevalence of sampled dogs.

\section{Conclusions}

This cross-sectional study shows that not all dog owners vaccinate their dogs and that the vaccines conferred protection beyond 12 months. The Preventive vaccination against rabies virus is a highly effective method for preventing rabies in humans and animals. Policies to enhance mass mandatory annual vaccination to achieve $70 \%$ coverage should be implemented in order to eradicate rabies.

\section{Keywords}

Rabies; Antibody; Antirabies vaccine; Abuja Nigeria; Dog owners

\section{Acknowledgments}

We acknowledge the MacArthur Foundation MSc. Epidemiology, Department of Veterinary Public Health and Preventive Medicine Ahmadu Bello University Zaria the sponsorship for O.G. Oladiran/Vet. Med./53282/ABU2012-2013.

\section{References}

1. Adedeji, A.O., Eyarefe, O.D., Okonko, I.O., Ojezele, M.O., Amusan, T.A. and Abubakar, M.J. (2010). Why is there still rabies in Nigeria? A review of the current and future trends in the epidemiology, prevention, treatment, control and possible elimination of rabies., $1(1), 10-25$.

2. Rupprecht, C. E., Smith, J. S., Fekadu, M. and Childs J. E. (1995). The ascension of wildlife rabies: a cause for public health concern or intervention? Emerging Infectious Diseases, 1:107-114.

3. Health Organization: WHO expert consultation on rabies. WHO Technical Report Series 981. Geneva, Switzerland, WHO. 2013.

\section{*Grace O. OLAYEMI}

E-mail: olamigracie@yahoo.com 